\title{
Universiteit
}

Leiden

The Netherlands

\section{Africa's Religious Resurgence and the Politics of Good and Evil}

\author{
Ellis, S.; Haar, G. ter
}

\section{Citation}

Ellis, S., \& Haar, G. ter. (2008). Africa's Religious Resurgence and the Politics of Good and Evil. Current History, 107(708), 180-185. Retrieved from https://hdl.handle.net/1887/13018

Version:

Not Applicable (or Unknown)

License:

Leiden University Non-exclusive license

Downloaded from: https://hdl.handle.net/1887/13018

Note: To cite this publication please use the final published version (if applicable). 
"At a time when 'development'-the notion that bureaucratic, secular government will lead to unprecedented prosperity-has for many lost its appeal, religion provides alternative ways of organizing society and politics and of thinking about the world."

\title{
Africa's Religious Resurgence and the Politics of Good and Evil
}

\author{
STEPHEN ELLIS AND GERRIE TER HAAR
}

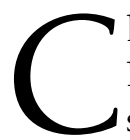

harles Taylor, the former president of Liberia, can be found every workday sitting in the dock of a small, bright, ultramodern courtroom in The Hague. Taylor is accused of responsibility for some of the grav-

\section{RELIGION AND STATE \\ Last in a series} est crimes imaginableatrocities committed in Liberia's neighbor to the northwest, Sierra Leone, during that country's 1991-2002 civil war. The crimes include authorizing mass recruitment of child soldiers, mass rape, and hacking off the hands of hundreds of people. Yet Taylor is known as a man who devotes considerable attention to religious matters. His example serves as a reminder that combining the practice of religion with the use of extreme violence is not as unusual as one might think.

The ex-president does not dispute that these crimes actually occurred. Nor does he deny that equally terrible things happened in his own country during the war that was fought there, off and on, between 1989 and 2003. But the charges against him concern Sierra Leone, not Liberia. And he maintains that the atrocities perpetrated in Sierra Leone were none of his doing. It is the first time an African head of state has ever stood trial before an international tribunal. Taylor is appearing before the Special Court for Sierra Leone-a hybrid body created jointly by the state of Sierra Leone and the United Nations. The case is being

STEPHEN ELLIS is a senior researcher at the African Studies Center at Leiden University. GERRIE TER HAAR is a professor at the Institute of Social Studies in The Hague. They are the authors of Worlds of Power: Religious Thought and Political Practice in Africa (Oxford University Press, 2004). heard in the Netherlands rather than West Africa for security reasons: Taylor still has a few influential friends in the region.

Most of the time Taylor, born in Liberia in 1948, resembles nothing so much as the benign patriarch of a wealthy family. He wears a dark business suit, a silk tie, and lightly tinted glasses. He has a chunky gold watch on his wrist. He chats affably with his lawyers. Yet not only is he standing trial for war crimes; his eldest son, Charles Taylor Jr., better known as "Chuckie," currently awaits trial in Florida on charges of torture.

Taylor's speeches, in the days when he was Liberia's head of state (1997-2003), were full of extravagant references to Jesus. He once declared to a mass rally that Jesus Christ was the true president of Liberia, and he is often described as having been a Baptist preacher. It is also reported that he joined the Nation of Islam during the year when he was held in a Massachusetts jail awaiting extradition to his home country. (Taylor had escaped to America from Liberia in 1983-apparently with $\$ 900,000$ of government money in his possession-after a dispute with the country's military dictator. Detained by US authorities at the request of the Liberian government, which wanted to try him for embezzlement, Taylor escaped from the Plymouth House of Correction in 1985.)

A decade later, shortly before he was elected president of Liberia, at a time when he was still just one of the country's many rival warlords, Taylor formally adopted a title indicating that he was a senior member of a traditional initiation society, a religious institution widespread in Liberia and surrounding areas. Former colleagues describe him as constantly soliciting the advice of prophets, healers, and diviners. Clearly, his religious 
allegiances are multiple and eclectic. In Africa, this too is not unusual.

What sort of religion is it that preoccupies such a man? If Taylor is truly religious, one may wonder, then how could he have done the terrible things he did in Liberia, and how could he even be suspected of the crimes he is accused of committing in Sierra Leone? Indeed, his religious activities are not simply designed to attract public support, as are those of many cynical politicians in search of votes. Throughout his career, and not only in public but also in private, Taylor has associated himself with a wide variety of religious specialists, including priests, prophets, and preachers, reputable and otherwise.

\section{SOURCES OF POWER}

Most politicians in Africa do the same. Many of them show every sign of seriousness in their search to communicate with an invisible world. So too do the fighters in wars all over the continent who seek amulets or perform rituals that they hope and believe will protect them from harm. Politicians and fighters alike seek power from the spirit world.

It is actually quite common in Africa to engage in practices from various religious traditions simultaneously, as in the case of churchgoers who also pour libation on the ground in honor of their ancestors, or Muslim clerics who make bracelets containing passages from the Koran that people buy for good luck. At least until recently, it was normal for many people in Africa to assess religious practices not by their adherence to a body of dogma, but according to whether the practices were thought successful in obtaining health and wellbeing. Perceived effectiveness has always been an acid test of religious ideas and practices for most people in Africa.

Everywhere you go in Africa today, from the great cities of the Mediterranean coast to Cape Town in the far south, the importance of religion is plain for all to see. Mosques, churches, and other places of worship are everywhere. It is common to see people worshipping or performing other religious activities in public. And politicians publicly cultivate religious constituencies. This resurgence of religion in public sometimes appears to Westerners as part of a worldwide religious revival—but this is not strictly accurate. In the case of Africa, religion has never gone away. What is new is only its salience in societies that are formally governed by secular states.

\section{THE INVISIBLE WORLD}

Religion in sub-Saharan Africa consists of a belief in the existence of an invisible world, distinct but not separate from the visible one, that is home to spiritual beings with effective powers over the material world. This statement, of course, does not describe religious belief for every person in this large, diverse region. A few Africans claim to be atheists or to think about religion differently from this. Still, it describes the prevalent perspective. Indeed, it is quite likely that most of the world's people think of religion rather as Africans do, in the sense that they believe in an invisible world and consider it real.

In the West, on the other hand, people tend to think of religion as a form of expression, comparable to art or music but more profound, something that gives ultimate meaning to human life. Even some regular churchgoers doubt that spiritual beings "really" exist. They may regard references to the Holy Spirit, for example, as a metaphor describing certain aspects of the human condition. One Christian minister in the Netherlands even describes himself as an atheist. In the same vein, Americans and Europeans often refer to African religious ideas with loaded words like "magic" or "superstition," which somehow disqualify these ideas from representing "real" religion. But in fact no intellectual justification exists for using pejorative terms when discussing African religious ideas and practices.

When considering the relationship between religion and politics in Africa today, it is helpful to regard religion as a morally neutral concept. Before colonial times, most Africans appear to have thought of the spirit world as in principle amoral. In other words, the spirit world's moral stance depended on the nature of the relationship between a person and a spirit, just as in a relationship between two people. Spiritual power could be invoked for benign purposes (personal healing and social harmony, for example) but also for malign purposes, such as to harm an enemy. 
The rapid spread of Christianity and Islam in the past century has challenged this perception, since both are dualistic religions, with God as the supreme good at one end of a moral continuum, and evil situated at the other, in the form of Satan. Previously, an angry spirit could be pacified and rendered neutral or benign by human action. Nowadays, certain spirits are regarded as evil by nature. Nothing can be done to change them.

\section{TOOLS FOR LIVING}

The very existence of a widespread belief in the spirit world turns this spirit world into a political instrument. Thus, many Africans use a spirit idiom to express dissatisfaction with poor governance. Examples from all parts of the continent show that politicians often see spiritual movements as a threat. Spiritual movements may be armed, like the Lord's Resistance Army in Uganda. They also may be unarmed, like the "barefoot" Muslim movement in Mali, or the Tablighi preachers in West Africa's Sahel region. Many political militants and even guerrilla fighters use spiritual techniques to increase their effectiveness, such as the fighters in eastern Congo who believe that amulets can make them immune by turning bullets into water. This is in keeping with the notion that reality not only consists of what can be observed in the material world, but also includes experiences of an invisible realm.

The idea that a part of the world is experienced by humans but is not visible is not as odd as it may sound. Even Western secularists believe that reality includes invisible forces or entities, such as debt, capital, and social structure. Capital, to take just one example, is itself invisible; it becomes visible only when it takes certain forms, most obviously as money or real estate. Money (which we can see and feel) and capital (an abstract quality that may be applied to physical objects) are not the same thing. What is most worth noting is the characteristics that people perceive such entities to have, and the techniques that people develop to relate to them. A Wall Street banker may attempt to manipulate capital in his own interest; someone else may try to communicate with a spirit for similar reasons. It is in part by means of interacting with unseen ideas that humans shape the world in which they live.

African politicians typically pay great regard to the spirit world as a source of power. Many heads of state cultivate diviners and marabouts to enhance their authority, as did Taylor and every recent Liberian president before him. This does not imply that these politicians are naive or oth- erworldly, or that they have no understanding of the material aspects of politics. Like most of their countrymen, they believe that spiritual power can help them succeed. When a president such as Taylor or Zaire's Mobutu Sese Seko turns to the spirit world for help in destroying his enemies, he does so in deadly earnest. The sociologist Max Weber, writing just after the First World War, observed that "he who lets himself in for politics, that is, for power and force as means, contracts with diabolical powers." Hundreds of millions of Africans would agree.

An idea central to African concepts of religionan idea shared by presidents and farmers, ministers and street cleaners-is that not only does an invisible world exist, but it is possible to communicate with it. Throughout Africa, common techniques for such communication include dreams, visions, spirit possession, and religious trances. The reasoning is simple: If an invisible world exists that is home to spirits-whether Muslim, Christian, or other-and if these spirits are as powerful as people believe, then it makes sense to enlist their help to succeed in this world, to be healthy and prosperous, to have a contented family.

Underlying this view is the assumption that material existence cannot be detached from the spirit world, where life is thought to originate. A farmer may revere his ancestors in order to seek their help in making crops grow or rain fall. A market woman may ask a healer to provide her with an amulet that will attract customers. A politician may want something that helps win an election. A fighter wants protection from bullets. It is widely believed that effective techniques exist for obtaining all these things.

\section{BEYOND DIVERSITY}

If Americans and Europeans sometimes find it difficult to appreciate the changing role of religion in African life (and no doubt in much of the rest of the postcolonial world), it is because of their own particular history. Early European travelers to Africa three or four centuries ago often thought that Africans had no religion at all, because they could not find any holy scriptures, sacred buildings, or a more or less organized priesthood-all of which they associated with the concept of religion. More recently, generations of colonial officials and ethnographers tended instead to identify "ethnic religions" that form parts of distinctive cultural traditions, so that scholarly books were written, for example, on Yoruba religion or Zulu religion. 
The reality has always been both simpler and more complex. Most African societies appear to have had no word corresponding exactly to the English word "religion" before the arrival of European missionaries. The Yoruba of southwestern Nigeria, for example, used to refer to what we would now call religious practices as "making country fashion," according to the British scholar John Peel. Religious practice was a technique for living, and in the many areas without writing and without sacred texts, rituals could quite easily incorporate changes in religious attitudes and practical conditions. Religious beliefs were rather undogmatic.

It is true that Islam and Christianity have existed in parts of Africa for over a thousand years, but neither made mass conversions outside a few areas until the nineteenth century. Both have grown very fast in the past few decades, resulting in a bewildering variety of different sorts of Christian churches and different types of Islam. Asian religions have also established roots in various parts of the continent, as have a great variety of new religious movements. There are also self-conscious revivals of some indigenous religions.

Africa's history of rather flexible religious belief runs up against the dogmatic nature of religions that have scriptures, yet

Africans remain generally tolerant in religious matters. Where people have claimed religious reasons for inflicting violence, as happens sporadically in Nigeria, it is when religion has become a tool in the hands of politicians. In recent decades, only the conflict in southern Sudan has come close to being a religious war in the strict sense-and the fact that in Darfur Muslims are killing other Muslims makes the point that all of Sudan's wars have been far more about politics and resources than about religion.

Indeed, beyond the apparent diversity and conflict, it is striking just how much is shared by the forms of belief found in Africa. One such example derives from the continent's deep attachment to oral culture, as a consequence of which many ideas (including religious ones) are passed on by word of mouth rather than in writing. African Christians and Muslims of course revere written texts, the Bible and the Koran respectively. But many of the ideas that people entertain about these scriptures, and many ideas inspired by them, are passed on mostly through face-to-face discussions. Also common to the various types of religion in Africa is-again-a deep-seated awareness that a spirit world exists and that people can interact with it effectively.

\section{IN THE PUBLIC SQUARE}

In Europe, two centuries or more of public life were marked by an absorbing search for a solution to the problems caused by the rival claims of politics and religion, claims that caused havoc across much of the continent in the sixteenth and seventeenth centuries. Over time, Europeans found an answer to their problem with the institutional separation of church and state. This tradition was also exported to North America by early settlers of European origin, and was continued constitutionally in the United States. One consequence has been the relegation of religion to a particular place in European life, and to a lesser extent in American life, as a largely private affair.

So effective has been this mental separation that Europeans find it hard to imagine any other way of doing things. Over two or three centuries Westerners have developed intellectual frameworks for understanding the world that are inseparable from European history. The manner in which the social sciences evolved in the West, for example, means that some of them, particularly sociology and political science, from their inception portrayed religion as an obstacle to progress.

In keeping with the prevailing view that people should be governed by secular states, Europeans took their ideas and their institutions with them to Africa. One of the main effects of colonial government was to establish secular, bureaucratic systems of government at the national level, where generally nothing comparable had existed previously. Colonial rule was thus an attempt to impose on Africa a form of government through the modern, literate organs of a secular state whose core function was to maintain a monopoly on violence. When colonial intellectuals and officials, soon joined by those Africans whom they trained in modern techniques of thought and bureaucratic action, got to work in Africa, they were applying their ideas to a continent in which governance by means of religion had a long pedigree. Colonial rule was intended as a rupture with many aspects of that history. 
The current resurgence of religion in Africa's public spaces is not lost on the continent's politicians. Some have declared themselves to be bornagain Christians, like Zambia's former president Frederick Chiluba, who went so far as to claim that his country was a "Christian nation." Senegal's President Abdoulaye Wade publicly prostrated himself before a Muslim leader, suggesting that the civil power was subservient to religious authority, contrary to that country's constitution.

As in other parts of the world, religious gestures such as these might make it look as though people are casting off the secular institutions that were imposed in colonial times and reverting to an older way of looking at things. But too much has changed in the past hundred years for us to think that Africa is simply returning to the past. Rather, today's religious revivals should be considered as reconfigurations of the resources available for a successful life todayincluding spiritual resources.

Nor can the persisMany Africans use a spirit idiom to express dissatisfaction with poor governance. of Africa, notably those often referred to as "failed states" or "fragile states."

Those African states that face acute problems of governance today are not so much failed states as imploded ones. Governance continues, although not through the ideal mechanism of an efficient, state-centered bureaucracy. In the absence of such an apparatus, the governance of sub-Saharan societies increasingly takes place through religion, as was also the case in precolonial times. Examples include the turn toward sharia (Islamic law) in some Muslim countries, the revival of traditional initiation societies in West Africa especially, and the rise of Christian revival movements. This profound rearrangement of religion and politics is about ideas. Religious ideas indicate how earnestly people are grasping to control the forces that they feel are shaping their lives. Rather than using the vocabulary of social science, they perceive these forces as spiritual in nature.

African countries' recourse to religious networks and practices, and their allowing them to have a gion be understood as a refusal to modernize. Even Islamic radicalism, when looked at closely, demonstrates an ability to adapt to modern life. It clearly has assimilated some aspects of Western influence, such as an appreciation for the uses of information technology. The reasons for the resurgence of religion in Africa lie not in a failure to escape from the past, but in an attempt to take control over the powerful forces that currently drive the lives of individuals and communities. People are doing this in the ways they know best.

\section{THE ILLEGITIMATE STATE}

When we consider religion's occupation of public space in Africa today-for example, in the form of politicians making religious gestures, and people praying and preaching in the city streetswe are witnessing something with a long and important history. It is, in fact, something that has always been intimately connected with patterns of governance, notwithstanding colonial and early nationalist attempts to govern Africa by secular institutions on the European model. The states that were instituted by colonial rulers, who generally left Africa 40 or more years ago but whose work was continued by nationalist administrators and politicians, are now in difficulty in many parts bearing on governance, reflect a widespread informalization of spheres of governance that, according to international norms, should be organized by a state. Hence it has become conventional to speak of informal economies and informal political systems, sometimes called "shadow states." Politics may take a religious form as people debate political questions in religious language.

The new dynamics of religion in public space (not only in Africa but throughout many formerly colonized territories) challenge the legitimacy of states that operate through institutions and norms of governance that were created in colonial times. Institutions inherited from the colonial period lack legitimacy not only because they have become increasingly ineffective, but also because they are seen as having little or no spiritual basis.

In fact, the democratization movement that began in the 1990s has been very important in projecting religion in the public realm. Democratic reform in this era was associated with the disappearance of some ideologies that had previously been dominant; this development created space for the emergence of religious ideologies as political vehicles. In Africa, rather sudden and radical political changes in the 1990s encouraged the irruption of spiritual movements into politi- 
cal space as people sought alternative sources of authority, and at the same time were freed from institutional constraints previously imposed by single-party governments.

\section{SHORTFALLS OF "DEVELOPMENT"}

At a time when "development"-the notion that bureaucratic, secular government will lead to unprecedented prosperity-has for many lost its appeal, religion provides alternative ways of organizing society and politics and of thinking about the world. These ways are often global, but may also be rooted in local traditions. The importance of religion has been noticed by some development experts, including at the World Bank, where James Wolfensohn, during his presidency, encouraged a series of meetings with leaders of various faith communities. Researchers are increasingly beginning to focus on the role of religion in the development process.

The 1950s and 1960s were the golden age of development in Africa. These years also witnessed the longest and widest economic boom in the history of the world. Millions of people moved from villages to towns. Many gained salaried employment. They sent their children to school. Develop- ment planners generally saw this as a movement from tradition to modernity, and they neglected the spiritual aspect of this transition, seeing religion as an obstacle to progress.

Yet it is now evident that, for many people, progress is not a material issue only. Furthermore, development too often has failed to deliver even the material benefits it promised. Many people in Africa experience some of the consequences of development as negative or harmful-especially the exposure to unemployment that comes with incorporation into a wage economy in societies that were largely agrarian until just a couple of generations ago. They often express this feeling of alienation in a spirit idiom.

The trial of Charles Taylor is already producing details of some horrific crimes and more will surely emerge in the year and a half that it is likely to continue. It is hard to think of terms strong enough to apply to the casual amputation of people's limbs by drugged adolescents or the perpetration of mass rape with refinements of cruelty. Many West Africans see these behaviors as the expression of a metaphysical evil that is channeled through human beings. That is how politics becomes not just a profession or a technique, but a matter of good and evil. 